\title{
APPLICATION OF DOI INDEX TO ANALYSIS OF SELECTED EXAMPLES OF RESISTIVITY IMAGING MODELS IN QUATERNARY SEDIMENTS
}

\author{
Michal Glazer ${ }^{1}$, Maciej Jan Mendecki², Mateusz Mycka² \\ ${ }^{1}$ Department of Geomorphology, Faculty of Earth Sciences, University of Silesia, Będzińska 60, \\ 41-200 Sosnowiec,e-mail:m.glazer@o2.pl \\ ${ }^{2}$ Department of Applied Geology, Faculty of Earth Sciences, University of Silesia, Będzińska 60, \\ 41-200 Sosnowiec,e-mails: maciej.mendecki@us.edu.pl,matueszmycka@gmail.com
}

\begin{abstract}
Interpretation of resistivity cross sections may be in many cases unreliable due to the presence of artifacts left by the inversion process. One way to avoid erroneous conclusions about geological structure is creation of Depth of Investigation (DOI) index maps, which describe durability of prepared model with respect to variable parameters of inversion. To assess the usefulness of this interpretation methodology in resistivity imaging method over quaternary sediments, it has been used to one synthetic data set and three investigation sites. Two of the study areas were placed in the Upper Silesian Industrial District region: Bytom-Karb, Chorzów-Chorzów Stary; and one in the Southern Pomeranian Lake District across Piława River Valley. Basing on the available geological information the results show high utility of DOI index in analysis of received resistivity models, on which areas poorly constrained by data has been designated.
\end{abstract}

Key words: depth of investigation index (DOI), electric resistivity tomography (ERT), resistivity model.

Manuscript received 8 May 2014, accpeted 4 November 2014

\section{INTRODUCTION}

Nowadays resistivity imaging method is commonly used in investigation of quaternary sediments for a number of purposes, from structural, geotechnical, hydrogeological environmental studies. Basing on apparent resistivity measurements on site of investigation, a model that would generate those data is tried to be found. It is achieved through solving the inverse problem. Because it is nonunique issue, modern strategies cope with this by using optimization techniques, so that among all available models choose those that in realistic way may represent geological structure. Resistivity imaging surveys do not give satisfactory results in areas where the thickness of layers is small and resistivity variations are low (Kowalczyk et al., 2014). Furthermore, model obtained in this way may possess numerical artifacts associated with minimization of objective function and caused by complex structure of earth, high resistivity contrast of bodies etc. To avoid misleading interpretations Oldenburg and $\mathrm{Li}$ (1999) proposed the use of Depth of Investigation (DOI) Index. They have characterized DOI as a persistence of a model while inversion parameters vary. Quantitatively it is made by comparing two inversion models created by utilization of different reference models in the optimalization function. This approach has been used in the works of, among others, Marescot et al. (2003), Hilbich et al. (2009), Deceuster et al. (2014).

\section{SITE CHARACTERISTIC}

Four of the analyzed resistivity profiles were used as the verification of applicability of DOI index to study shallow geological structure. First three profiles were located in the Upper Silesia Industrial District in city areas of Bytom and Chorzów. Fourth investigation site was placed in the South Pomeranian Lake District, northwestern Poland, in the vicinity of the Pile Lake and Długie Lake. The purpose of those measurements was to identify the localization of the depth of Miocene-Pleistocene boundary which in this area is very variable (Lewandowski et al., 2000).

In Bytom, surveys were carried out in district of Karb near the cross-road of the main route $88 \& 94$. Quaternary deposits in this place were formed as sands, loamy sands and sandy loam. They are covering bedrock represented by the thick layer of Triassic (the Buntsandstein and the Muschelkalk) lying on Carboniferous (Razowska-Jaworek \& Brodziński, 2009).

Second site has been placed in Chorzów, district Chorzów Stary, contiguous to Siemianowicka Street and close to 
ARRANGEMENT OF MODEL BLOCKS AND APPARENT RESISTIVITY DATUM POINTS

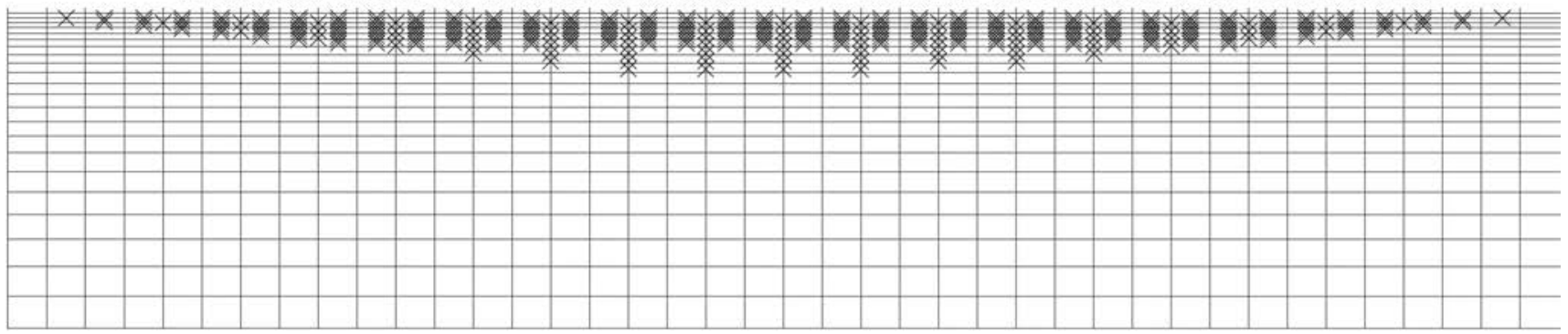

$\square$ Model block

$\times$ Datum point Number of model layers is 22
Maximum pseudodepth is 20.0

Minimum pseudodepth is 1.82

Number of electrodes is 41

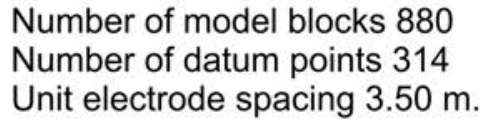

Fig. 1. Arrangement of the model cells used in the DOI calculation and location of the data points in the apparent resistivity pseudosection for Bytom-Karb profile. As the geometrical dimensions are dependent on electrode spacing the length and depth are expressed in terms of pseudolenght and pseudodepth.

the Silesia Park. Quaternary consists of sands, loam sands, and dusty clays which are product of Carboniferous layer erosion. It covers Carboniferous mudstones and sandstones (Wyczółkowski, 1597, Cudak \& Wantuch, 2009).

Last area of study includes headwaters of the Pilawa river valley and neighboring areas, located west from the center of Borne Sulinowo town. The Miocene deposits were developed as a sands, clays and silts. The maximum thickness of the Miocene deposits is about 160 meters (Dobracka, Piotrowski,2002; Lewandowski et al., 2000). It is covered by a Pleistocen complex in which five glacial horizons composed of tills formed during the glaciation can be distinguished. The Pleistocene sediments range from 70 to $200 \mathrm{~m}$ (Lewandowski et al., 2000; Żogała et al., 2008; Idziak, Wysowska-Świebodzińska, 2008). In this area glaciotectonic deformation of the substratum and erosion of pre-Pleistocene structures cause large variations of formation and intensive disturbances within the roof layers of the Miocene. The egzaration depressions of subglacial tunnels and geotectonic elevations occurs (Lewandowski et al., 2000). Structures of the Holocene are mainly developed in the form of sand, river gravels, silts, gyttja, lacustrine chalk and peat (Żogała et al., 2008).

\section{METHODOLOGY}

The resistivity imaging measurements were performed with the ABEM Lund Imaging System. Depending on the area of studies and its purpose different electrode spacings have been applied. At all sites the Wenner-Schlumberger protocol has been used as a compromise for lateral and perpendicular sensitivity (Loke, 2014). The inversion of resistivity data was carried out in RES2DINVx64 ver. 4.03.13 program. Routine inversion formulation used in this software is based on the Gauss-Newton smoothness-constrained leastsquares $\left(l_{2}\right.$-norm) optimization method that gives smooth changes in spatial resistivity of models. Depending on the situation user can modify it to $1_{1}$-norm where the absolute difference between the measured and calculated apparent resistivity values is minimized. This will result in searching for a model with sharp boundaries (Loke et al., 2003). With the exception of Piława River Valley, all measurements have been carried out on flat terrain.

To estimate the reliability of prepared resistivity models depth of investigation (DOI) index method has been used. It was introduced by Oldenburg and Li (1999) and at first used for mountain permafrost studies by Merescot et al. (2003). It is the empirical method based on comparison two different inversions of the same data set using various values of the reference model. According to Oldenburg and Jones (2007) the DOI value for a model cell is given by:

$$
R_{A B}(x, z)=\frac{\left|q_{A}(x, z)-q_{B}(x, z)\right|}{\left|q_{A}-q_{B}\right|}
$$

where $q_{A}(x, z)$ and $\mathrm{q}_{B}(x, z)$ are the model cell resistivities obtained from the first and second inversions, $q_{A}$ and $q_{B}$ are the first and second reference models resistivities values. All of them are expressed in terms of logarithm of resistivity (Deceuster et al., 2014). Merescot et al. (2003) recommended using the reference models set at 0.1 and 10 times arithmetic mean of the measured apparent resistivity. This is known as two sides difference. In regions where the result depend strongly on data DOI will take values near zero, while in regions where values depend more on objective function parameters, in this case the reference model, DOI will rise to one.

Vertical position of the data point (Fig.1) is set at the median depth of investigation of the electrode configuration (Edwards, 1977). To ensure that the data have minimal information about the resistivity of the cells in the lowest layer, the depth range of the inversion model is extended of about three to five times the median depth of investigation of largest array spacing used (Loke, 2014). In theory, the bottom cells in this arrangement have DOI values of almost 1.0 but in practice it depends on the damping factor that controls the degree of influence of the given reference model to inversion model. To reduce the effect of chosen damping factor Oldenburg and Li (1999) and Marescot et al. (2003) proposed to scale the DOI through its maximum value. Hilbich et al. (2009) suggested to normalize it by the use of DOI value at the bottom of the model. In this paper all profiles were extended fivefold but only those parts that overlap with interpretable 
High Resistivity Lens- Synthetic Model

\section{Distance $[\mathrm{m}]$}
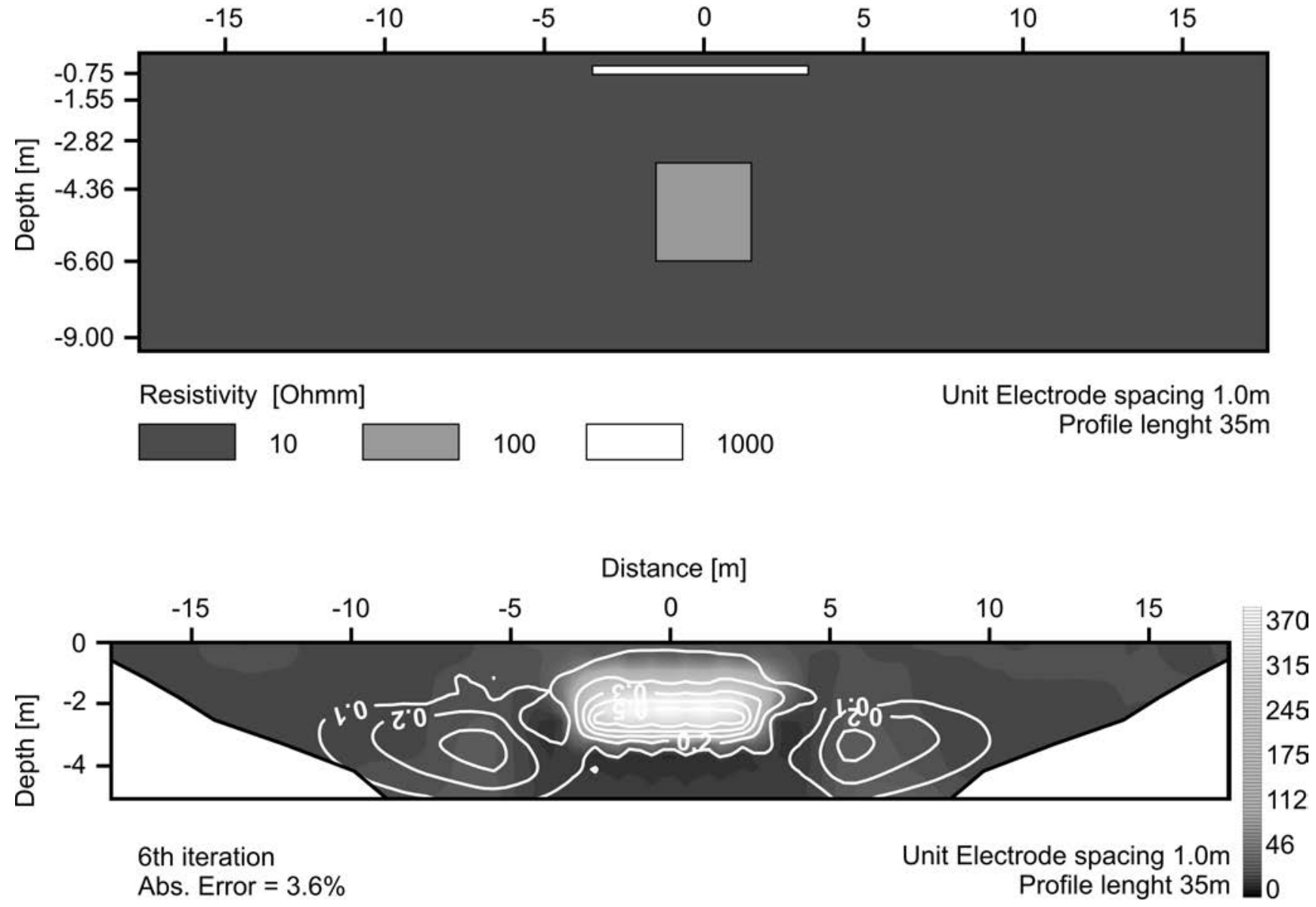

Fig. 2. High resistivity lens synthetic model and its inversion model generated from obtained response over the earth overlapped with DOI index map.

models are presented, moreover all profiles at their bottom cell row showed DOI values approaching 1 . Only Chorzów Stary diverged from that and was scaled by max DOI index of the bottom row. In RES2DINV software DOI preparation routine, damping factor $\mu$ (RES2DINV manual, 2014) which responsible for impact on the reference model has been chosen to set it to its greatest value. To check applied methodologies synthetic model has been created in RES2DMOD software using wenner-schlumberger array with $1 \mathrm{~m}$ electrode spacing and subsequently analyzed with DOI index. As a cutoff value of DOI index (i.e. value of DOI index that above which we have to be very cautious with interpretacion of resistivity models) Oldenburg and Li (1999) firstly suggested to be 0.1 or 0.2 . Caterina et al. (2013) proposed to use the maximum gradient line of the DOI rather than a predefined value to determine depth of investigation. In turn Oldenburg and Jones (2007) prefered index of 0.3. In these works cutoff value is determined individually for every profile.

\section{RESULTS - THEORETICAL MODELING}

Constructed model (Fig. 2) represents a high resistivity lens of $0.2 \mathrm{~m}$ thickness and $6.5 \mathrm{~m}$ length buried at depth $0.5 \mathrm{~m}$. Its resistivity was set to $1000 \mathrm{Ohmm}$ while its background has $10 \mathrm{Ohmm}$. Underneath resides a body of $100 \mathrm{Ohmm}$ resistivity. Imposed map of DOI index shows high variations at the bottom of this anomaly reaching values of 0.5 . Two symmetric variabilities can be observed at both sides of profile with maximum DOI of 0.3 . They coincide with slight resistivity anomalies from the background level.

\section{RESULTS - PRACTICAL EXAMPLES}

\section{Bytom-Karb}

Three main geological formations can be distinguished on resistivity cross-section on Fig. 3. Near surface there is discontinuous anomaly with resistivity values range from 40 to $60 \mathrm{Ohmm}$ which are assigned to dry sands. They cover layer of very low resistivity, 10-40 Ohmm, interpreted as loamy sands. Relatively high resistivity values from 60 up to $200 \mathrm{Ohmm}$ that can be found on the bottom of profile are interpreted as Triassic strata.

DOI index takes very small values on this profile. In most of its area it does not exceed 0.075 . Only at the depth of $10-15 \mathrm{~m}$ below $0-15 \mathrm{~m}$ of profile length it range from 0.1 to 0.125 . 


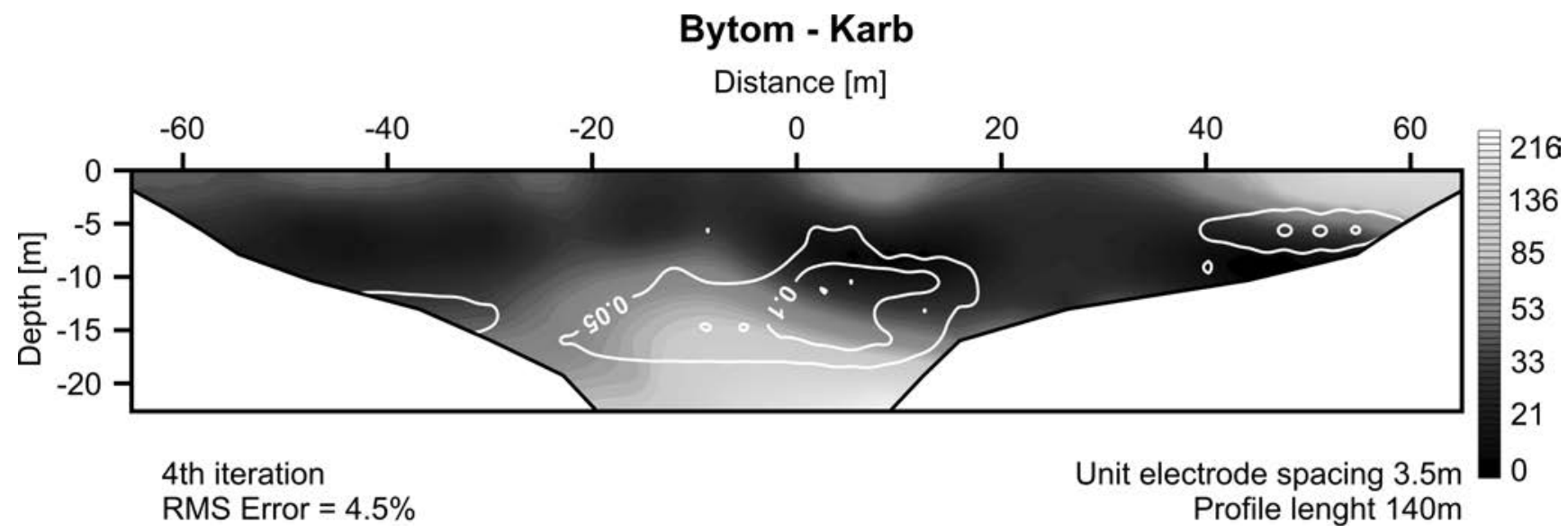

Fig. 3. Resistivity cross-section from Bytom - Karb investigation site, overlapped with DOI index map.

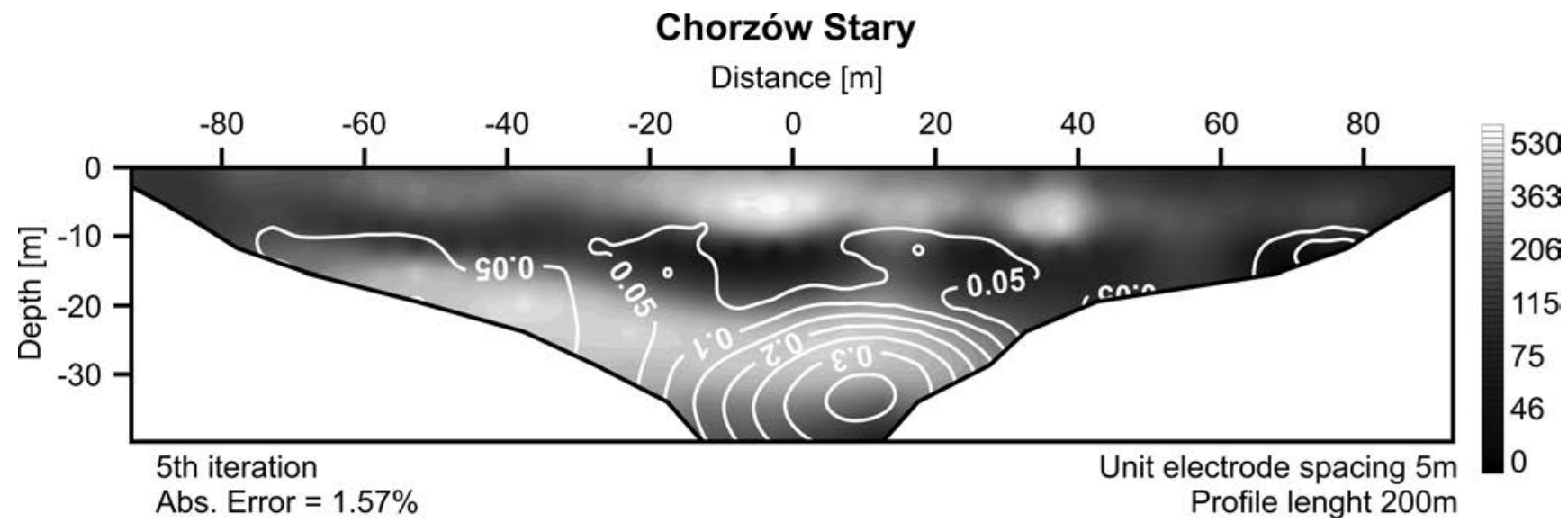

Fig. 4. Resistivity cross-section from Chorzów Stary investigation site, overlapped with DOI index map.

\section{Chorzów Stary}

On Fig. 4 the 200-meter-long resistivity profile from Chorzów Stary is presented. Near surface there is a Quaternary sand insert 200-500 Ohmm. It lays on weathered Carboniferous dusty clays and its resistivity range from 10 to 100 Ohmm. This overburdes covers the Carboniferous rigid strata with resistivities above $300 \mathrm{Ohmm}$. Beneath this high resistivity anomaly, sudden decline in the value of resistivity, down to $100 \mathrm{Ohmm}$, is observed.

Map of DOI index shows sudden increase of its values, up to 0.35 , that corresponds to low resistivity anomaly under top of Carboniferous.

\section{Pilawa River Valley}

Only resistivity imaging method has been used in this study area, nevertheless good correlation has been achieved with documentacion from nearby hydrogeologic borehole. On geoelectrical model presented at Fig. 5. four different resistivity layers can be distinguished. Upper layer varies from 700 to $3000 \mathrm{Ohmm}$. Its maximum thickness is $20 \mathrm{~m}$. This complex do not show itself on entire profile but only at distances $0-130 \mathrm{~m}, 320-410 \mathrm{~m}$ and 510 up to the end. It is well correlated with sands from sandur plane, however its middle part may have different, fluvial or limnoglacial, origin. At the distances 230-330 and 370-570 m, partially under the first complex, there can be separated second one with resistivity changes from 100 to 300 Ohm. Basing on works of Klimek and Lewandowski (2002), it is related to sands, gravels and sandy and clayey sediments. Its floor undulates in range 10 to $30 \mathrm{~m}$. Underneath rests separate complex characterized by resistivity values variable from 30 to $90 \mathrm{Ohmm}$. It contains predominantly tills with sand and gravel interbeddings. Its floor falls gently to the west, up to the distance 440m where it rapidly goes down. The floor is considered as a Miocene-Pleistocene boundary. Similar zone of distinct lowering, north from this profile, was confirmed by Żogała et al. (2008) that is correlated with assumable ice-sheet margin range of Pomerian phase of North-Polish Glacial. It is thought that it is an outcome of two factors: subglacial tunnel slope and unconsolidated sediments compaction The Miocene sedimentary complex is composed of sands, silts and dusts. Its resistivity values are higher than Pleistocene tills and range from 200 to $1500 \mathrm{Ohmm}$. DOI index values generally stay under 0.3 above $130 \mathrm{~m}$ of depth. Under this horizon they start to increase drastically. Exception from that is area at profile distance -215 and depth of $60 \mathrm{~m}$. Here DOI increases up to 0.4 . 


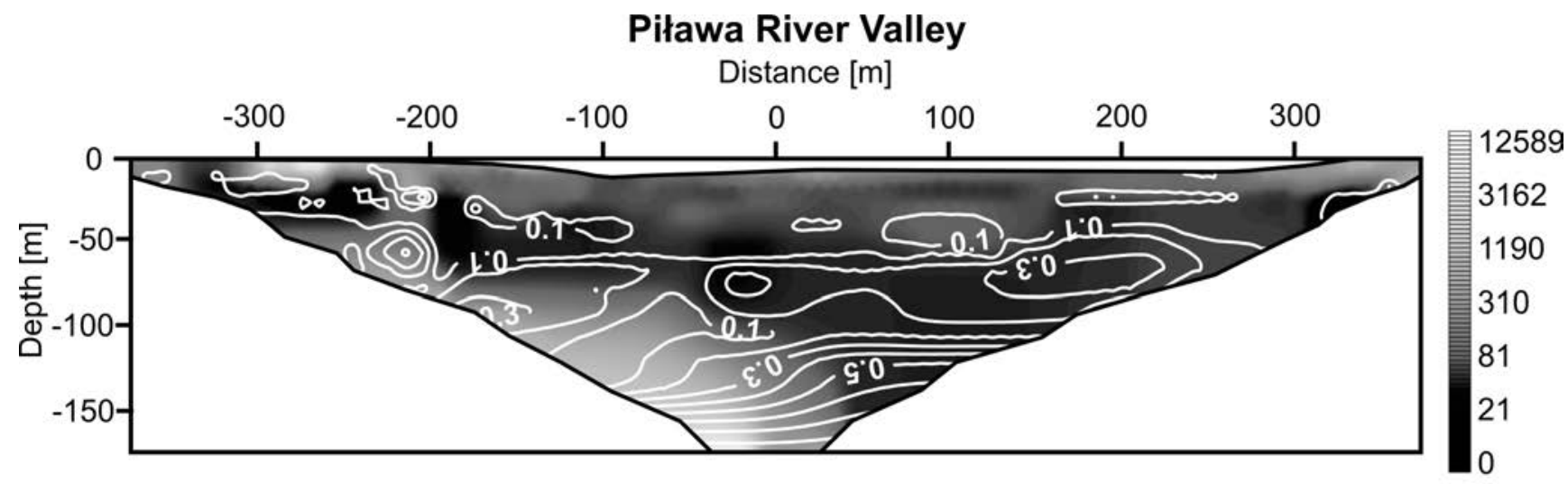

6th iteration

Abs. Error $=8.2 \%$

Unit Electrode spacing 10m

Profile lenght $800 \mathrm{~m}$

Fig. 5. Resistivity cross-section across Piława River Valley, overlapped with DOI index map.

\section{DISCUSSION AND CONCLUSIONS}

Two inversion models obtained with different reference models will look similar in regions affected directly by data set, while in other regions they will approach their reference resistivity. Comparison of those two inversion models gives us direct information about how large was the influence of objective function that has been used.

In inversion model obtained from synthetic data set (Fig. 2.) real body that cause high resistivity anomaly is very thin $(0.2 \mathrm{~m})$ and lies just below the surface. The effect of its presence is that resistivity imaging method "scope of vision" is blocked not only just below but it in serious way affect the possibilities to distinguish geological structure lying much deeper. Depth of Investigation index helps to determine reliability of achieved high resistivity anomaly. In this case the cut-off factor can be set at 0.3 we can assume cut-off factor. It is worth to pay attention to symmetrical DOI anomalies on both sides of high resistivity lens and caused by it.

On Bytom-Karb profile all values of DOI are very low. It means that gathered data set constrain generated inversion model very well. Although slight variations can be observed near highly deformed ceiling of Triassic strata.

In case of investigation site in Chorzów Stary, high increase DOI index can be spotted below ceiling of Carboniferous rigid strata. This fact calls into question generated resistivity values of the bottom of inversion model. It may be that thin but high resistivity layer of the carboniferous lies on layer with relatively lower resistivities or high contrast between dusty clay-bedrock and insufficient amount of data from this depths causes extortion, by optimalization equation, of low resistivity layer.

Resistivity cross-section across Piława River Valley shows high values below $130 \mathrm{~m}$ depth. It should be considered not to interpret DOI above 0.3 . Area at profile distance -215 and depth of $60 \mathrm{~m}$ is exceptionally interesting because high DOI over there may suggest that there is no vertical connection between highly resistivity layers at the top and bottom of the profile and this structure is only "artifact" of inversion.

Depth of Investigation index proved to be very helpful to determine reliability of generated inversion models for Qua- ternary resistivity imaging studies. This methodology should be incorporated into the standard processing and interpreting procedures of resistivity data.

\section{Acknowledgements}

The project was partially funded by the National Science Centre granted under Decision No UMO-2012/05/N/ST10/03943 and by University of Silesia from the resources of student activates (donation for Student Science Society of Geophysics).

\section{REFERENCES}

Caterina D., Beaujean J., Robert T.,Nguyen F.,2013, A comparison study of different image appraisal tools for electrical resistivity tomography. Near Surface Geophysics, 11, 639-657

Cudak J., Wantuch A. (2009) Chorzów [In:] Groundwater of Polish cities. Cities over 50000 inhabitants (in Polish), ed. Z. Nowicki. Państwowy Instytut Geologiczny Warszawa. (Website accessed 26.04.2014) http://www.psh.gov.pl/plik/id,4743.pdf

Deceuster J., Etienne A., Tanguy R., Nguyen F., Kaufmann O., 2014, A modified DOI-based method to statistically estimate the depth of investigation of dc resistivity surveys, Journal of Applied Geophysics, 103, 172-185.

Dobracka E., Piotrowski A., 2002, Geological structure and morphology of sub-Quernary surface, Proc. $9^{\text {th }}$ Conference "Pleistocene Stratigraphy of Poland", 85-92, (in Polish).

Edwards L.S., 1977, A modified pseudosection for resistivity and inducted-polarization, Geophysics 42, 1020-1036.

Hilbitch C., Marescot L., Hauck C., Loke M.H., Mausbacher R., 2009, Applicability of electrical resistivity tomography monitoring to coarse blocky and ice-rich permafrost landforms, Permafrost and Periglacial Processes, 20, 269-284.

Idziak A.F., Wysowska-Świebodzińska A., 2008, Geophysical survey of post-glacial deposits, ActaGeodynamica et Geomaterialia., 5, No. 2 (150), p. 197-203.

Klimek K., Lewandowski J., 2002, Pilawa river valley. Proc. 9th Conference Pleistocene Stratigraphy of Poland, 161-166, (in Polisch).

Kowalczyk S., Zawrzykraj P., Mieszkowski R., 2014, Application of electrical resistivity tomography in assessing complex soil conditions, Geological Quarterly, 59 (2), (Website accessed 26.06.2014) http://www.gq.pgi.gov.pl/article/view/10390/ pdf 1166

Lewandowski J., Heliasz Z., Chybiorz R., 2000, Explanations to de- 
tail geological map of Poland, Lubowo sheet. Polish Geological Institute. Warsaw, (in Polish).

Loke M.H., 2014, Tutorial: 2-D and 3-D electrical imaging; surveys in: http://www.geoelectrical.com (Website accessed 26.04. 2014)

Loke M.H., Acworth I., Dahlin T., 2003, A comparison of smooth and blocky inversion methods in $2 \mathrm{D}$ electrical imaging surveys, Exploration Geophysics 34, p. 182-187.

Marescot L., Loke M.H., Chapellier D., Delaloye R.,Lambiel C., Reynard E., 2003 Assesing reliability of 2D resistivity imaging in mountain permafrost studies using the depth of investigation index method, Near Surface Geophysics, 1(2), 57-67.

Oldenburg D. W., Jones F.H.M., 2007, Inversion for Applied Geophysics; Learning resources about geophysical inversion, University of British Columbia: Geophysical Inversion Facility, http://www.eos.ubc.ca/ubcgif/iag/index.htm (Website accessed 26.04.2014)
Oldenburg D.W., Li Y., Estimating depth of investigation in dc resistivity and IP surveys, Geophysics 64(2), 403-416.

Razowska-Jaworek L., Brodziński I., 2009, Bytom [In:] Groundwater of Polish cities. Cities over 50000 inhabitants (in Polish), ed. Z. Nowicki. Państwowy Instytut Geologiczny Warszawa. (Website accessed 26.04.2014) http://www.psh.gov.pl/ plik/id,4742.pdf

RES2DINV manual, 2014, http://www.geoelectrical.com (Website accessed 26.04.2014)

Wyczółkowski J., 1597. The Detailed Geological Map of Poland, scale 1:50 000, sheet Zabrze, M34-62A, Geological Institute, Warsaw (in Polish)

Żogała B., Dubiel R., Lewandowski J., Zuberek W.M., Gąska G., 2008, Application of resistivity imaging method for investigation of geologic structure of Pleistocene sediments, Acta Geodynamica et Geomaterialia., Vol. 5, No. 2 (150), p. 177-183. 